\title{
Assessment of Knowledge and Practices of Parents Regarding Infant Oral Health Care in Chennai City - A Cross Sectional Study
}

\author{
Vaishnavi S. ${ }^{1}$, Preetha Elizabeth Chaly ${ }^{2}$, Nijesh J.E. ${ }^{3}$ \\ 1Department of Public Health Dentistry, Tagore Dental College and Hospital, Chennai, Tamilnadu, India. \\ 2, 3 Department of Public Health Dentistry, Meenakshi Ammal Dental College and Hospital, Chennai, Tamilnadu, India.
}

\section{ABSTRACT}

\section{BACKGROUND}

There is a general agreement that the oral cavity of an infant is sterile at birth but is soon contaminated with a flora predominantly streptococcal in nature. This is the first habitat in human body where microorganisms are seen to be established soon after the birth within 6 to 8 hours in an infant. Since parents are the decision makers with regard to child oral health care, the study was conducted to assess the knowledge and practices of parents regarding infant oral health care in Chennai city.

\section{METHODS}

The survey was carried out among parents of infants attending a government and a private children's hospital in Chennai city. Cluster sampling methodology was used to recruit 400 parents of infants. Based on Kuppuswamy socioeconomic scale, 400 parents were divided into 3 classes. Data about the knowledge and practices of parents regarding infant oral health care were collected using a pre-tested questionnaire. Chi-square test was used for statistical analysis.

\section{RESULTS}

The overall results showed that $49.6 \%$ of parents have correct knowledge and 37.8 $\%$ of parents were following correct practices. The results among the three social classes showed that $44.25 \%$ of the lower class, $46.8 \%$ of the middle class, $58.5 \%$ of the upper-class parents have correct knowledge and $35.5 \%$ of the lower class, 36.3 $\%$ of the middle class, $41.9 \%$ of the upper-class parents were following correct practices.

\section{CONCLUSIONS}

The study concluded that the parents of infants have low level of knowledge about infant oral health care and they were following improper feeding practices. As the socioeconomic status increases there is marginally better understanding of infant oral health knowledge and practices.

\section{KEY WORDS}

Infant Oral Health Care, Kuppuswamy Socio-Economic Scale, Knowledge, Practices
Corresponding Author:

Dr. Vaishnavi $S$,

Department of Public Health

Dentistry, Tagore Dental

College and Hospital,

Rathinamangalam,

Melakkottaiyur (P.O),

Chennai-600 127,

Tamilnadu, India

E-mail: vaishnaviprashanth1@gmail.com

DOI: $10.14260 / j e m d s / 2020 / 863$

How to Cite This Article:

Vaishnavi S, Chaly PE, Nijesh JE. Assessment of knowledge and practices of parents regarding infant oral health care in Chennai city-a cross sectional study. J Evolution Med Dent Sci 2020;9(52):39453949, DOI: 10.14260/jemds/2020/863

Submission 20-08-2020,

Peer Review 05-11-2020,

Acceptance 11-11-2020,

Published 28-12-2020.

Copyright (c) 2020 Vaishnavi S. et al. This is an open access article distributed under Creative Commons Attribution License [Attribution 4.0 International (CC BY 4.0)] 


\section{BACKGROUND}

Child development from conception through the first years of life is marked by many changes. Tooth eruption at about 6 months of age is a milestone both in terms of functional and psychological changes in the child's life and in emotional terms for the parents. ${ }^{1}$ The period from birth till 3 years is the most crucial from oral health point of view as during this period primary tooth buds are developing, the dietary habits of a child are being formed and the bacterial ecology is being

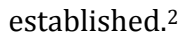

Nursing caries is a frustrating condition that is difficult to treat infants and very young children. It may retard the child's health; it's infectious, and results in impairment of nutrition and aesthetics with accompanying psychological problems. ${ }^{3}$ Primary preventive methods incorporated at early age can modify the risk factors for dental caries and gingival diseases and make the child have a good quality of life. ${ }^{2}$

The family is the child's dominant social environment in early childhood. Researchers have focused on modifying the infant diet and feeding habits by educating the parents. ${ }^{3}$ In recent years' attention has been focused on planning programs on infant dental care in various countries. Knowledge of parents on maintaining their child's oral health on early stages of development of teeth plays an important role in preventing many oral diseases. ${ }^{4}$ So the present study was carried out to assess the knowledge and practices of parents of infants selected from general population regarding oral health of their infants, to guide and educate them for prevention of early childhood caries. ${ }^{2}$

\section{METHODS}

A cross-sectional study was carried out to assess the knowledge and practices of parents of infants regarding infant oral health care in Chennai city. The study was approved by the institutional review board. For pilot study, 50 parents attending government hospital and 50 parents attending private hospital in Chennai city were surveyed to know the feasibility of the study, check for the reliability and validity of the questionnaire and to estimate the sample size. The sample size was calculated using the given formula

$$
\frac{(\mathrm{Z} 2 \mathrm{x}[\mathrm{p}] \mathrm{x}[\mathrm{q}])}{\triangle^{2}}
$$

Where $\mathrm{Z}=\mathrm{Z}$ value for confidence chosen $(1.96$ for $95 \%$ confidence interval)

$\mathrm{P}=50 \%=0.50$ (percentage of parents who had positive knowledge and practices)

$\mathrm{q}=1-\mathrm{p}=0.50$

$\triangle=$ margin of error which is acceptable $=0.50(5 \%)$

Therefore,

Sample size $=(\{1.96\} 2 \times\{0.50\} \times\{0.50\} /(0.50) 2=384$

Thus, sample size was rounded off to 400 . It was decided to take 400 parents of whom 200 parents from government hospital and 200 from private hospital so that it would cover people from different socio-economic groups.
Cluster random sampling methodology was used. Among the hospitals in Chennai city which were providing health care exclusively to the children, four hospitals were selected randomly of which two were government hospital and two were private hospital. All the parents of infants who were willing to participate were invited to participate to reach the required sample size.

Parents of infants who have visited the government and the private hospital and attended the OPD on the day of interview were included in the study.

Parents who were not willing to participate, parents of disabled infants and infants who were undergoing treatment for any diseases were excluded from the study. A specially designed closed ended questionnaire which consisted of questions based on knowledge and practices of infant oral health care was used. Questionnaire also consisted of basic information including age, gender, ordinal status and socioeconomic status of the family.

Based on Kuppuswamy socioeconomic scale, 400 parents were divided into 3 classes. It was classified based on the education, occupation and income of the head of family. ${ }^{5}$ The upper and upper middle class were categorised as upper class, lower middle class was categorized as lower class and upper lower and lower class were categorized as lower class. The statistical analysis was done using chi square test.

Data was analysed using the SPSS software version 11.5 (SPSS Inc., Chicago, IL, USA). Descriptive statistics was used to summarise the sample and responses of the questionnaire. Pearson's chi square test was used to assess the relationship between the KAP score and the demographic characteristics. Pearson correlation is used to estimate the correlation between the knowledge and practice scores of all the groups. A significant relationship was assumed to exist between the groups if the $\mathrm{P}$ value was found to be lesser than $5 \%$ (P $\leq$ 0.05).

\section{RESULTS}

The final sample consists of 400 parents from three different social classes. 163 were parents of male infants and 237 were parents of female infants. The distribution of parents according to their social classes is shown in figure 1 . The mean age of the child (in months) along with standard deviation is given in table 1 . The responses of the parents to the questions regarding knowledge of their infant's oral health care are given in table 2 and practices of their infant's oral health care are given in table 3 . The overall correlations between knowledge score and practice score is 0.345 and the correlation between knowledge score and practice score for lower group is 0.411 , middle group is 0.176 , and for upper group is 0.182 .

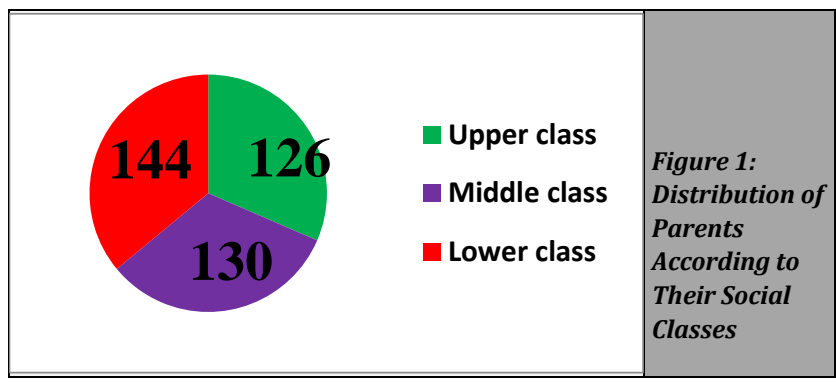




\begin{tabular}{|cccc|}
\hline Group & N & Mean Age of Child in Months & S.D. \\
Lower & 144 & 5.31 & 2.957 \\
Middle & 130 & 5.94 & 3.357 \\
Upper & 126 & 5.50 & 3.293 \\
Total & 400 & 5.57 & 3.201 \\
\hline \multicolumn{3}{|c|}{ Table 1. Mean Age of the Infants (in Months) } \\
\hline
\end{tabular}

\begin{tabular}{|c|c|c|c|c|c|c|c|}
\hline \multirow[b]{2}{*}{$\begin{array}{l}\text { Sl. } \\
\text { No }\end{array}$} & \multirow[b]{2}{*}{ Questions } & \multirow[b]{2}{*}{ Responses } & \multicolumn{4}{|c|}{ Group } & \multirow[b]{2}{*}{$\begin{array}{c}\text { P } \\
\text { Value }\end{array}$} \\
\hline & & & $\begin{array}{l}\text { Lower } \\
\text { N (\%) }\end{array}$ & $\begin{array}{l}\text { Middle } \\
\text { N (\%) }\end{array}$ & $\begin{array}{l}\text { Upper } \\
\text { N (\%) }\end{array}$ & $\begin{array}{l}\text { Total } \\
\text { N \% }\end{array}$ & \\
\hline 1. & $\begin{array}{l}\text { Do you think mother's } \\
\text { diet during pregnancy } \\
\text { will affect baby's } \\
\text { teeth? }\end{array}$ & Yes & $\begin{array}{c}87 \\
(60.4)\end{array}$ & $\begin{array}{c}84 \\
(64.6)\end{array}$ & $\begin{array}{c}99 \\
(78.6)\end{array}$ & $\begin{array}{c}270 \\
(67.5)\end{array}$ & 0.004 \\
\hline 2. & $\begin{array}{l}\text { Do you think bacteria } \\
\text { will be present in your } \\
\text { child's mouth within } \\
\text { few hours after birth? }\end{array}$ & Yes & $\begin{array}{c}43 \\
(29.9)\end{array}$ & $\begin{array}{c}58 \\
(44.6)\end{array}$ & $\begin{array}{c}90 \\
(71.4)\end{array}$ & $\begin{array}{c}191 \\
(47.8)\end{array}$ & 0.001 \\
\hline 3. & $\begin{array}{l}\text { Do you know the } \\
\text { harmful effects of } \\
\text { feeding while } \\
\text { sleeping? }\end{array}$ & $\begin{array}{c}\text { Causes } \\
\text { dental caries }\end{array}$ & $\begin{array}{c}32 \\
(22.2)\end{array}$ & $\begin{array}{c}41 \\
(31.5)\end{array}$ & $\begin{array}{c}75 \\
(59.5)\end{array}$ & $\begin{array}{l}148 \\
(37)\end{array}$ & 0.001 \\
\hline 4. & $\begin{array}{l}\text { Do you think cleaning } \\
\text { gum pad and tongue } \\
\text { before eruption of } \\
\text { teeth is essential? }\end{array}$ & Yes & $\begin{array}{c}99 \\
(68.8)\end{array}$ & $\begin{array}{c}81 \\
(62.3)\end{array}$ & $\begin{array}{c}101 \\
(80.2)\end{array}$ & $\begin{array}{c}281 \\
(70.3)\end{array}$ & 0.007 \\
\hline 5. & $\begin{array}{l}\text { When do you think } \\
\text { you can start cleaning } \\
\text { your child's gum pad? }\end{array}$ & $\begin{array}{l}\text { Within first } \\
\text { week after } \\
\text { birth }\end{array}$ & $\begin{array}{c}7 \\
(4.9)\end{array}$ & $\begin{array}{c}15 \\
(11.5)\end{array}$ & $\begin{array}{c}14 \\
(11.1)\end{array}$ & $\begin{array}{c}36 \\
(9.0)\end{array}$ & 0.094 \\
\hline 6. & $\begin{array}{l}\text { What time do you } \\
\text { think is ideal to take } \\
\text { your child to the } \\
\text { dentist? }\end{array}$ & $\begin{array}{l}6-12 \\
\text { months }\end{array}$ & $\begin{array}{c}13 \\
(9.0)\end{array}$ & $\begin{array}{c}13 \\
(10.0)\end{array}$ & $\begin{array}{c}14 \\
(11.0)\end{array}$ & $\begin{array}{c}40 \\
(10)\end{array}$ & 0.850 \\
\hline 7. & $\begin{array}{l}\text { Do you think decayed } \\
\text { teeth could affect } \\
\text { child's general health? }\end{array}$ & Yes & $\begin{array}{c}32 \\
(22.2)\end{array}$ & $\begin{array}{c}36 \\
(27.7)\end{array}$ & $\begin{array}{c}63 \\
(50.0)\end{array}$ & $\begin{array}{c}131 \\
(32.8)\end{array}$ & 0.001 \\
\hline 8. & $\begin{array}{l}\text { Which month do you } \\
\text { think is ideal for } \\
\text { weaning? }\end{array}$ & $\begin{array}{c}6-12 \\
\text { months }\end{array}$ & $\begin{array}{c}121 \\
(84.0)\end{array}$ & $\begin{array}{c}107 \\
(82.3)\end{array}$ & $\begin{array}{c}110 \\
(87.3)\end{array}$ & $\begin{array}{c}338 \\
(84.5)\end{array}$ & 0.001 \\
\hline 9. & $\begin{array}{l}\text { Do you know the safe } \\
\text { limit of total sugar } \\
\text { exposure in a day for } \\
\text { prevention of dental } \\
\text { caries? }\end{array}$ & $\begin{array}{c}\text { Thrice per } \\
\text { day }\end{array}$ & $\begin{array}{c}2 \\
(1.4)\end{array}$ & $\begin{array}{c}4 \\
(3.1)\end{array}$ & $\begin{array}{c}7 \\
(5.6)\end{array}$ & $\begin{array}{c}13 \\
(3.3)\end{array}$ & 0.155 \\
\hline 10. & $\begin{array}{l}\text { Do you think bacteria } \\
\text { will be transmitted } \\
\text { from you to your } \\
\text { child? }\end{array}$ & Yes & $\begin{array}{c}91 \\
(63.2)\end{array}$ & $\begin{array}{c}78 \\
(60.0)\end{array}$ & $\begin{array}{c}109 \\
(86.5)\end{array}$ & $\begin{array}{c}278 \\
(69.5)\end{array}$ & 0.001 \\
\hline \multicolumn{8}{|c|}{ Table 2. Knowledge of Parents Regarding Infant Oral Health Care } \\
\hline & -significant & & & & & & \\
\hline
\end{tabular}

\begin{tabular}{|c|c|c|c|c|c|c|c|}
\hline $\begin{array}{l}\text { Sl. } \\
\text { No }\end{array}$ & Questions & Responses & $\mathrm{s}_{\%}^{\text {Lowe }}$ & $\begin{array}{l}\text { Gro } \\
\text { Middle } \\
\%\end{array}$ & $\begin{array}{l}\text { up } \\
\text { Upper } \\
\%\end{array}$ & $\begin{array}{c}\text { Tota } \\
\%\end{array}$ & $\underset{\text { Value }}{P}$ \\
\hline 1. & $\begin{array}{l}\text { When did you think you } \\
\text { can first start cleaning } \\
\text { your child's teeth? }\end{array}$ & $\begin{array}{l}\text { As soon as } \\
\text { first tooth } \\
\text { erupts }\end{array}$ & $\begin{array}{c}54 \\
(37.5)\end{array}$ & $\begin{array}{c}47 \\
(36.2)\end{array}$ & $\begin{array}{c}77 \\
(61.1)\end{array}$ & $\begin{array}{c}178 \\
(44.5)\end{array}$ & 0.001 \\
\hline 2. & $\begin{array}{l}\text { Do you remove the } \\
\text { bottle immediately after } \\
\text { feeding your child? }\end{array}$ & Yes & $\begin{array}{c}77 \\
(53.5)\end{array}$ & $\begin{array}{c}75 \\
(57.7)\end{array}$ & $\begin{array}{c}65 \\
(51.6)\end{array}$ & $\begin{array}{c}217 \\
(54.2)\end{array}$ & 0.155 \\
\hline 3. & $\begin{array}{c}\text { What are the postures of } \\
\text { your child while bottle } \\
\text { fed? }\end{array}$ & Upright & $\begin{array}{c}67 \\
(46.5)\end{array}$ & $\begin{array}{c}52 \\
(40.0)\end{array}$ & $\begin{array}{c}61 \\
(48.4)\end{array}$ & $\begin{array}{l}180 \\
(45)\end{array}$ & 0.360 \\
\hline 4. & $\begin{array}{c}\text { Do you clean your child's } \\
\text { mouth / give water after } \\
\text { every feed? }\end{array}$ & $\begin{array}{l}s \\
r\end{array}$ & $\begin{array}{c}4 \\
(2.8)\end{array}$ & $\begin{array}{c}1 \\
(0.8)\end{array}$ & $\begin{array}{c}8 \\
(6.3)\end{array}$ & $\begin{array}{c}13 \\
(3.2)\end{array}$ & 0.039 \\
\hline 5. & $\begin{array}{l}\text { How will you clean your } \\
\text { baby's mouth? }\end{array}$ & $\begin{array}{l}\text { Clean moist } \\
\text { cloth / } \\
\text { finger }\end{array}$ & $\begin{array}{c}104 \\
(72.2)\end{array}$ & $\begin{array}{c}91 \\
(70.0)\end{array}$ & $\begin{array}{c}84 \\
(66.7)\end{array}$ & $\begin{array}{c}279 \\
(69.8)\end{array}$ & 0.152 \\
\hline 6. & $\begin{array}{l}\text { Do you have the habit of } \\
\text { cleaning your child's } \\
\text { mouth after giving } \\
\text { medicated syrup? }\end{array}$ & Yes & $\begin{array}{c}7 \\
(4.9)\end{array}$ & $\begin{array}{c}11 \\
(8.5)\end{array}$ & $\begin{array}{c}43 \\
(34.1)\end{array}$ & $\begin{array}{c}61 \\
(15.2)\end{array}$ & 0.001 \\
\hline 7. & $\begin{array}{c}\text { Have you ever cleaned } \\
\text { your child's gum pad } \\
\text { before eruption of teeth? }\end{array}$ & Yes & $\begin{array}{c}94 \\
(65.3)\end{array}$ & $\begin{array}{c}87 \\
(66.9)\end{array}$ & $\begin{array}{c}101 \\
(80.2)\end{array}$ & $\begin{array}{c}282 \\
(70.5)\end{array}$ & 0.015 \\
\hline 8. & $\begin{array}{l}\text { How many times will } \\
\text { you clean your child's } \\
\text { mouth? }\end{array}$ & Thrice & $0(.0)$ & $0(.0)$ & $2(1.6)$ & $2(0.5)$ & 0.278 \\
\hline 9. & $\begin{array}{l}\text { Has your paediatrician } \\
\text { ever discussed about } \\
\text { your child's oral health? }\end{array}$ & Yes & $\begin{array}{c}0 \\
(0)\end{array}$ & $\begin{array}{c}2 \\
(1.5)\end{array}$ & $\begin{array}{c}2 \\
(1.6)\end{array}$ & $\begin{array}{c}4 \\
(1.0)\end{array}$ & 0.321 \\
\hline \multicolumn{8}{|c|}{$\begin{array}{c}\text { Table 3. Response of Parents Regarding the Practices of } \\
\text { Infant Oral Health Care }\end{array}$} \\
\hline \multicolumn{8}{|c|}{$\mathrm{P}<0.05$-significant } \\
\hline
\end{tabular}

Most of the upper-class parents know about the harmful effects of feeding while sleeping and many of them were aware of appropriate age for weaning and not aware of starting age to clean the child's gum pad and about the ideal time to visit the dentist.

\section{DISCUSSION}

A cross-sectional survey was carried out to assess the knowledge and practices of parents of infants regarding infant oral health care in Chennai city. Feeding patterns are of prime importance in the aetiology of dental caries, especially nursing caries. Some dietary practices such as prolonged and at-will breast feeding, prolonged and nocturnal bottle feeding, and the use of sweetened comforters have been associated with nursing caries.

Tetracycline when administered to the pregnant mother, when the teeth are calcifying in the foetus, leads to discolouration of the teeth because the drug chelates the mineralizing hydroxyl apatite crystals of the enamel and produces brownish discolouration of the teeth. Pregnant women should be health conscious and consume healthy food during pregnancy and in the present study $67.5 \%$ of parents answered correctly that mother's diet during pregnancy will affect baby's teeth. Streptococcus is found to be consistently present within few hours after birth. ${ }^{2}$ and in the present study, overall, $47.8 \%$ of parents answered correctly that bacteria will be present in child's mouth within few hours of birth. Several reports suggest that even though parents know the harmful effects of putting the baby to sleep with the bottle, they still do it. In the present study overall $37.0 \%$ of parents answered correctly that feeding while sleeping will cause dental caries. A major risk factor for nursing caries is putting the child to bed with a bottle containing cariogenic fluids. This is due to the decrease in the salivary flow and the reduction of swallowing reflex as the child gets drowsier, allowing the carbohydrate to remain in the mouth and pool around the teeth while the child is asleep. In a study conducted by Manjot Kaur in Chandigarh, only $2 \%$ of parents reported that feeding while sleeping will cause dental caries and in a study conducted by Aljohara et al. $90 \%$ of mothers know about the harmful effects of feeding while sleeping, but still parents were feeding their child while sleeping. ${ }^{6}$ In a study conducted by Amjad et al. $22 \%$ of parents were practising feeding while sleeping. ${ }^{7}$ Parents should be advised not to put the child to bed with the bottle or at the breast and take the bottle away immediately after feeding.

In the present study, $2.3 \%$ of parents cleaned their baby's mouth with infant toothbrush, $0.8 \%$ of parents cleaned their baby's mouth with cotton, $2.0 \%$ with towel and $69.8 \%$ with finger. Whereas in a study conducted by Manjot Kaur, $17 \%$ of parents cleaned their child's gum pad with their fingers and $11 \%$ with a moist cloth. ${ }^{2}$ Parents should brush or clean their baby's gums / teeth every day till the child is old enough to manage themselves. It is well known that syrups and infant substitutes cause dental caries and in the present study, 15.3 $\%$ of parents answered that they will clean their child's mouth after giving medicated syrup and parents should be advised to avoid the extended use of sugared medicines such as syrups and they should clean their baby's mouth immediately after giving sugared medicines and in a study 
conducted by Sunayanamanipal et al. $90 \%$ of parents were aware that syrups and infant substitutes cause dental caries. ${ }^{8}$

Parents may not clean their child's gum pad due to the limited cooperation of infants and mothers may lack skill to efficiently clean their child's gum pad, and in the present study overall $70.3 \%$ of parents answered correctly that it is essential to clean gum pad and tongue before the eruption of teeth, and in a study conducted by Sunayanamanipal, $92 \%$ of parents answered that it is necessary to clean gum pad and tongue even before the teeth begin to erupt. ${ }^{8}$

In the present study only $9.0 \%$ of parents answered correctly that they should start cleaning their child's gum pad within first week of birth which is almost similar to the study conducted by Manjot Kaur where only $13 \%$ of parents were aware of the exact time of gum pad cleaning i.e., a week after birth. ${ }^{2}$ Thereby, showing the ignorance of most of the parents regarding the correct time of gum pad cleaning.

In the present study $44.5 \%$ of parents were aware of the fact that they should start cleaning their child's teeth as soon as first tooth erupts, and in a study conducted by Manjot Kaur, no one was aware about the initiation of cleaning their child's teeth. ${ }^{2}$ In the present study, only $3.2 \%$ of parents answered correctly that they should clean their child's mouth thrice daily, and in a study conducted by MG Gussy et al. approximately three quarters of parents reported cleaning their child's teeth frequently. ${ }^{9}$

Paediatrician and general practitioners are the first health professionals to come in contact with the expectant mothers and parents of infants. Hence, integrating oral health disease prevention and promotion strategies into these health care professionals practice would improve access to dental care, especially for the poor and minority children, and in the present study, $1.2 \%$ of parents replied that they have discussed about their child's oral health to paediatrician.

According to the American Academy of Paediatric Dentistry Guidelines, the recommended age for the first dental visits ranges from the time of eruption of the first tooth to 1 year of age, and in the present study, only $10 \%$ of parents answered correctly that $6-12$ months is the ideal time to take child to dentist. In a study conducted by Aljohara et al., only $9 \%$ of parents made their visit to the dentist at or before the age of 12 months. ${ }^{6}$ In the present study, $32.8 \%$ answered correctly that decayed teeth could affect child's general health and, in a study conducted by Robert J Schroth et al. $87.5 \%$ of parents responded that rotten teeth could affect child's health. ${ }^{10}$

An assessment was made about the knowledge of parents regarding the safe limit of total sugar exposure in a day for prevention of dental caries. The correct knowledge of safe limit being 3 times per day was seen in only $3.3 \%$ of parents which is similar to the study conducted by Manjot Kaur where $11 \%$ of parents answered correctly. ${ }^{2}$

The main source of infection is the transmission of caries causing bacteria to the children from their parents and can occur through infectious medias like feeding spoons, kisses on the mouth and whenever the mother cleans the infant's pacifier by sticking it into her own mouth and $69.5 \%$ of the parents were aware that bacteria will be transmitted from them to their child. The limitation of the study is that the sample size was small when considering each social class separately and the results of the study may not be applicable to population outside Chennai and in rural areas. As the child grows from infant to adulthood, oral health may change in course of time due to peer influences, environmental factors and awareness. Furthermore, studies should be conducted using a larger sample to make the results more reliable and valid.

The present study showed that overall upper social class parents seem to have better knowledge and follow correct practices. This maybe because of their better educational background, social and economic status and proper utilization of health care services.

Individuals from lower socioeconomic status experience financial, social and material disadvantages that compromise their ability to care for themselves, obtain professional healthcare services, and to live in a healthy environment, all of which lead to reduced resistance to oral and other diseases. After the interview, parents were educated on how to maintain their infant's oral health properly and were articulated on the importance of oral health care.

\section{Recommendations}

- Begin cleaning the infant's gums with gauze or a clean damp cloth after each feeding.

- Preferably infants should not be put to sleep with a bottle. Any bottle that is taken to bed should only contain water.

- After nursing, remove the breast from a sleeping infant's mouth and cleanse the gums and teeth (as soon as they erupt), after feedings and before bedtime.

- Clean your infant's mouth after giving medications that may contain sugary flavouring agents.

- Pacifiers should not be dipped in honey or milk and should never be cleaned in the parent's own mouth and then given to the infant.

- Never add honey or sugar to the baby's milk.

- Use a soft finger brush with a smear of non-fluoride toothpaste to clean the teeth as soon as the first tooth appears. As the infant develops more teeth, a safety brush may be used for brushing.

- Parents and caregivers should maintain their own oral health and never share utensils, cups, spoons or toothbrushes with the infant.

- $\quad$ Parents should start introducing the concept of drinking from a cup by 6 months of age and weaning infants from the bottle by age of 6 months to 1 year.

- Drinking juice from a bottle should be avoided. When juice is offered, a cup should be used and the juice should be given with meals.

- Parents should schedule the 1 st dental visit as early as 6 months and no later than 1 year. ${ }^{11}$

\section{CONCLUSIONS}

Parents have low level of knowledge about infant oral health care and they were following improper feeding practices. Oral diseases in infants are almost entirely preventable with proper oral hygiene and feeding practices that promote oral health. Many parents of infants and young children are in need of advice about feeding their infants and young children. Advice is required on avoidance of nocturnal bottle feedings, in particular with sweetened fluids, and prolonged bottle 
feeding. Further research is required to identify high risk parents and target these parents for efficient oral health promotion. As the socioeconomic status increases there is marginally better understanding of infant oral health knowledge and practices.

Data sharing statement provided by the authors is available with the full text of this article at jemds.com.

Financial or other competing interests: None.

Disclosure forms provided by the authors are available with the full text of this article at jemds.com.

\section{REFERENCES}

[1] Cunha RF, Boer FA, Torriani DD, et al. Natal and neonatal teeth: review of the literature. Pediatr Dent 2001;23(2):158-62.

[2] Kaur M, Goyal A. Assessment of knowledge and practices regarding infant oral health care in Chandigarh population. Journal of the Indian Association of Public Health Dentistry 2011;18(3):1102-8.

[3] Tyagi R. The prevalence of nursing caries in Davangere preschool children and its relationship with feeding practices and socioeconomic status of the family. J Indian Soc Pedod Prev Dent 2008;26(4):153-7.

[4] Mohebbi SZ, Virtanen JI, Vehkalahti MM. A community randomized controlled trial against sugary snacking among infants and toddlers. Community Dentistry and Oral Epidomiology 2012;40(1):44-9.

[5] Kumar N, Gupta N, Kishore J. Kuppuswamy's socio economic scale: updating income ranges for the year 2012. Indian J Public Health 2012;56(1):103-4.

[6] Al-Hussyeen AA, Al-Sadhan S. Feeding practices and behaviour of Saudi children with early childhood caries and dental knowledge of mothers. Saudi Dent J 2002:14(3);112-7.

[7] Wyne A, Spencer AJ, Szuster FS. Infant and child feeding practices: a preliminary investigation. Aust Dent J 1997;42(1):54-8.

[8] Manipal S, Joseph A, Prabhu D, et al. Knowledge, attitude of mothers on oral hygiene practices among 1-5 year old children and association with their oral hygiene practices - a comparative study. Annals and Essences of Dentistry 2012;4(4):19-23.

[9] Gussy MG, Waters EB, Riggs EM, et al. Parental knowledge, beliefs and behaviours for oral health of toddlers residing in rural victoria. Aust Dent J 2008;53(1):52-60.

[10] Schroth RJ, Brothwell DJ, Moffatt MEK. Caregiver knowledge and attitudes of preschool oral health and early childhood caries (ECC). Int J Circumpolar Health 2007;66(2):153-67.

[11] American Academy of Pediatric Dentistry Clinical Affairs Commity. Policy on dietary recommendations for infants, children and adolescents. Pediatr Dent 2008-2009;30(7 Suppl):47-8. 